Molecules 2001, 6, 852-868

molecules

ISSN 1420-3049

http://www.mdpi.org

\title{
Amine and Titanium (IV) Chloride, Boron (III) Chloride or Zirconium (IV) Chloride-Promoted Baylis-Hillman Reactions
}

\section{Min Shi*, Jian-Kang Jiang and Shi-Cong Cui}

Laboratory of Organometallic Chemistry, Shanghai Institute of Organic Chemistry, Chinese Academy of Sciences, 354 Fenglin Lu, Shanghai 200032 China. Fax: +86-21-64166263.

* Author to whom correspondence should be addressed; E-mail: mshi@pub.sioc.ac.cn.

Received: 27 April 2001; in revised form 11 October 2001 / Accepted: 18 October 2001 / Published: 31 October 2001

\begin{abstract}
The Baylis-Hillman reactions of various aryl aldehydes with methyl vinyl ketone at temperatures below $-20^{\circ} \mathrm{C}$ using Lewis acids such as titanium (IV) chloride, boron (III) chloride or zirconium (IV) chloride in the presence of a catalytic amount of selected amines used as a Lewis bases afford the chlorinated compounds $\mathbf{1}$ as the major product in very high yields. Acrylonitrile can also undergo the same reaction to give the corresponding chlorinated product in moderate yield. A plausible reaction mechanism is proposed. However, if the reaction was carried out at room temperature (ca. $20^{\circ} \mathrm{C}$ ), then the Z-configuration of the elimination product $\mathbf{3}$, derived from $\mathbf{1}$, was formed as the major product.
\end{abstract}

Keywords: Titanium (IV) chloride; boron (III) chloride; zirconium (IV) chloride; Bayliss-Hillman reaction; halogenation; Lewis base, amine.

\section{Introduction}

The Baylis-Hillman reaction and related processes, typically catalyzed by DABCO or tertiary phosphines, have become increasingly important in organic synthesis because the resulting adducts may have several functional groups available for numerous further transformations [1-5]. The major drawbacks 
of the Baylis-Hillman reaction are its slow reaction rate and a limited range of useful substrates. To overcome these shortcomings many variations have been devised, such as the use of Lewis acids or various other additives to activate the carbonyl electrophiles [6-10]. Among those Lewis acids examined, $\mathrm{TiCl}_{4}$ has been successfully used to promote the Baylis-Hillman reaction in the presence of Lewis base catalysts $[9,11,12]$. During our own investigations of the Baylis-Hillman process we found that many amines are very effective Lewis bases in this interesting reaction and the reaction products differ considerably from those reported so far [13]. Herein we wish to report the full details of the titanium (IV) chloride, boron (III) chloride or zirconium (IV) chloride and amine promoted Baylis-Hillman reactions, along with a plausible reaction mechanism based on the previous findings and our own results.

\section{Results and Discussion}

We initially attempted the reaction of $p$-nitrobenzaldehyde with methyl vinyl ketone in the presence of $\mathrm{TiCl}_{4}$ (1.0 eq) at $-78{ }^{\circ} \mathrm{C}$. No reaction occurred (Table 1, entry 1$)$. However, after adding $20 \mathrm{~mol} \%(0.20$ eq) of triethylamine $\left(\mathrm{Et}_{3} \mathrm{~N}\right)$ as a Lewis base, the reaction took place smoothly to give the chlorinated product 1a, rather than 2a and 3a (usually considered the Baylis-Hillman olefin and trisubstituted alkene) as reported by Kataoka and Li [9, 12], respectively (Scheme 1, Table 1, entry 2). By careful investigation, we found that this reaction was very sensitive to the amounts of both $\mathrm{TiCl}_{4}$ and amines present in the reaction mixture (Table 1). By means of catalytic amounts of amine and excess amounts of $\mathrm{TiCl}_{4}$ the reaction proceeded very well. However, using large excesses of amine as a Lewis base, the reaction was completely stopped (Table 1 , entry 6). This result suggested that the amine could coordinate to $\mathrm{TiCl}_{4}$ and that free $\mathrm{TiCl}_{4}$ acting as a Lewis acid was required to promote the reaction. The amount of $\mathrm{TiCl}_{4}$ was also crucial for this reaction because using a catalytic amount of $\mathrm{TiCl}_{4}$, the reaction became very slow and gave low yields of 1a (Table 1, entry 7 and 8). The best reaction conditions were found to be the use of $20 \mathrm{~mol}$ $\%$ of amine as a Lewis base and $1.4 \mathrm{eq}$ of $\mathrm{TiCl}_{4}$ as a Lewis acid (Table 1, entry 4 ).

Scheme 1

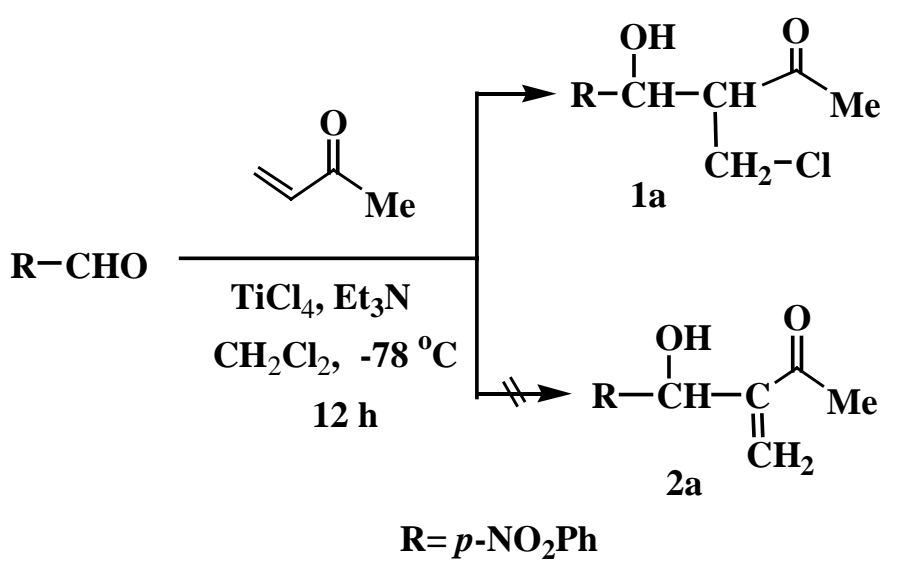


Table 1. Reaction Conditions for the Bayliss-Hillman Reaction of p-Nitrobenzaldehyde with Methyl Vinyl Ketone in the Presence of $\mathrm{TiCl}_{4}$ and $\mathrm{Et}_{3} \mathrm{~N}$

\begin{tabular}{|c|c|c|c|}
\hline Entry & $\begin{array}{c}\text { Eq. of Lewis } \\
\text { base }\left(\mathbf{E t}_{\mathbf{3}} \mathbf{N}\right)\end{array}$ & $\begin{array}{c}\text { Eq. of Lewis } \\
\text { acid }\left(\mathbf{T i C l}_{\mathbf{4}}\right)\end{array}$ & $\begin{array}{c}\text { Yield }^{\text {a) }}[\mathbf{\%}] \\
\mathbf{1 a}\end{array}$ \\
\hline 1 & 0 & 1.4 & 0 \\
2 & 0.05 & 1.4 & 60 \\
3 & 0.1 & 1.4 & 76 \\
4 & 0.2 & 1.4 & 81 \\
5 & 1.0 & 1.4 & 45 \\
6 & 6.0 & 1.4 & 0 \\
7 & 0.2 & 0.4 & 36 \\
8 & 0.2 & 0.8 & 54 \\
\hline \multicolumn{3}{|c|}{ a) isolated yields } \\
\hline
\end{tabular}

For many arylaldehydes having strongly electron-withdrawing group on the phenyl ring, the reactions proceed quickly to give compounds 1 in high yields using a catalytic amount of Lewis base $(20 \mathrm{~mol} \%)$ at $-78^{\circ} \mathrm{C}$ (Scheme 2, Table 2). However, other arylaldehydes or aliphatic aldehydes needed higher temperatures $\left(-20^{\circ} \mathrm{C}\right)$ to give the corresponding chlorinated product $\mathbf{1}$ in high to moderate yields. Moreover, we found that besides triethylamine, 1,8-diazabicyclo[5.4.0]undec-7-ene (DBU) and diethylamine were also very effective Lewis bases for this reaction in the presence of $\mathrm{TiCl}_{4}$ (Table 2).

\section{Scheme 2}
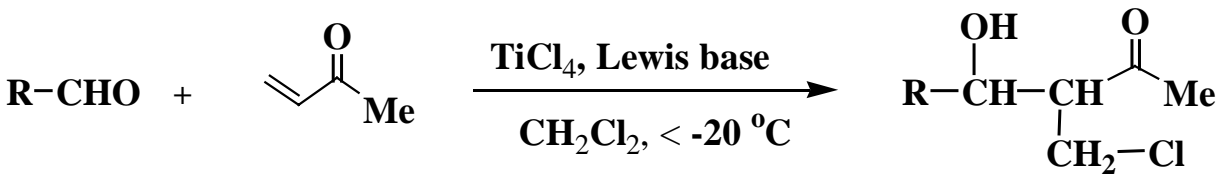

1a-e

a: $p-\mathrm{NO}_{2} \mathrm{Ph} ; \mathrm{b}: m-\mathrm{NO}_{2} \mathrm{Ph} ; \mathrm{c}: \boldsymbol{p}-\mathrm{CF}_{3} \mathrm{Ph} ; \mathrm{d}: \mathrm{Ph}$; e: $p$-EtPh; f: $p$-CIPh; g: $\mathrm{CH}_{3}\left(\mathrm{CH}_{2}\right)_{3}$.

All cases shown in Table 1 only needed a catalytic amount of amine $(20 \mathrm{~mol} \%)$ to bring the reaction to completion in the presence of $\mathrm{TiCl}_{4}$ (Table 2). It should be emphasized that in all cases, only one diastereomer was formed during the reaction process based on the ${ }^{1} \mathrm{H}-\mathrm{NMR}$ spectral data evidence. Their relative configurations were confirmed as the $s y n$-form by analysis of the X-ray crystal structure of 1a [13] (Figure 1). 
Table 2. Bayliss-Hillman Reaction of Aldehydes with Methyl Vinyl Ketone in the Presence of $\mathrm{TiCl}_{4}$ and $20 \mathrm{~mol} \%$ of Lewis Base

\begin{tabular}{|c|c|c|c|c|c|}
\hline Entry & $\mathbf{R}$ & Lewis base & $\begin{array}{c}\text { Temp } \\
{\left[{ }^{\circ} \mathbf{C}\right]}\end{array}$ & $\begin{array}{c}\text { Time } \\
{[\mathbf{h}]}\end{array}$ & $\begin{array}{c}\text { Yield }^{\mathbf{a})}[\%] \\
\mathbf{1}\end{array}$ \\
\hline 1 & $p-\mathrm{NO}_{2}-\mathrm{Ph}$ & none & -78 & 12 & - \\
2 & $p-\mathrm{NO}_{2}-\mathrm{Ph}$ & $\mathrm{Et}_{3} \mathrm{~N}$ & -78 & 12 & 81 \\
3 & $m-\mathrm{NO}_{2}-\mathrm{Ph}$ & $\mathrm{Et}_{3} \mathrm{~N}$ & -78 & 12 & 88 \\
4 & $p-\mathrm{CF}_{3}-\mathrm{Ph}$ & $\mathrm{Et}_{3} \mathrm{~N}$ & -78 & 48 & 80 \\
5 & $\mathrm{Ph}$ & $\mathrm{Et}_{3} \mathrm{~N}$ & -20 & 48 & 80 \\
6 & $p-\mathrm{Et}-\mathrm{Ph}$ & $\mathrm{Et}_{3} \mathrm{~N}$ & -20 & 48 & 72 \\
7 & $p-\mathrm{Cl}_{-} \mathrm{Ph}$ & $\mathrm{Et}_{3} \mathrm{~N}$ & -20 & 48 & 70 \\
8 & $\mathrm{CH}_{3}(\mathrm{CH})_{3}$ & $\mathrm{Et}_{3} \mathrm{~N}$ & -20 & 48 & 45 \\
9 & $p-\mathrm{NO}_{2}-\mathrm{Ph}$ & $\mathrm{Et}_{2} \mathrm{NH}$ & -78 & 12 & 88 \\
10 & $\mathrm{Ph}$ & $\mathrm{Et}_{2} \mathrm{NH}$ & -20 & 48 & 71 \\
11 & $p-\mathrm{NO}_{2}-\mathrm{Ph}$ & $\mathrm{DBU}$ & -78 & 12 & 82 \\
12 & $\mathrm{Ph}$ & $\mathrm{DBU}$ & -20 & 48 & 65 \\
\hline
\end{tabular}

a) isolated yields

Figure 1: Crystal Structure of 1a

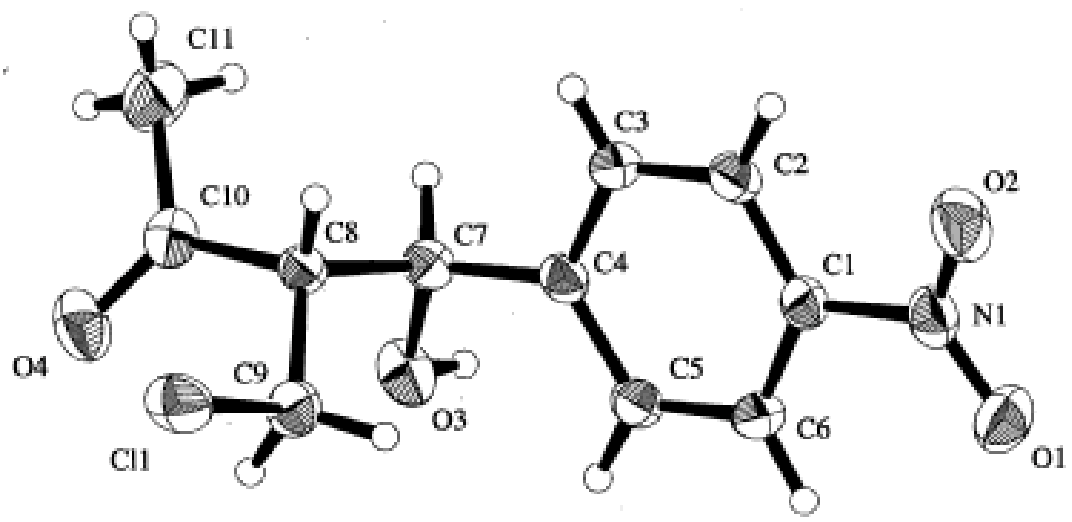

Compound 1 can be easily and completely transformed to the compound 2 [14] by treating with an excess amount (2.0 eq) of triethylamine or 1,8-diazabicyclo[5.4.0]undec-7-ene (DBU) (Scheme 3). The purification of $\mathbf{1}$ by preparative thin layer chromatography (TLC) was noted to also cause the transformation of $\mathbf{1}$ to $\mathbf{2}$, therefore quick flash column chromatography is required in order to obtain the pure product 1 . 
Scheme 3<smiles>[R]C(O)C(CCl)C(C)=O</smiles>

1a

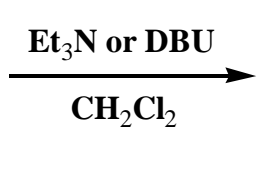

$\mathrm{R}=p-\mathrm{NO}_{2} \mathrm{Ph}$<smiles>[R]C(O)C(=C)C(C)=O</smiles>

2a

methyl vinyl ketone, acrylonitrile underwent the same reaction to give the corresponding chlorinated product $\mathbf{1 h}$ in moderate yield in $\mathrm{CH}_{2} \mathrm{Cl}_{2}$ at $10^{\circ} \mathrm{C}$ for 5 days (Scheme 4, Table 3, entries 1 and 2 ), but at $-78{ }^{\circ} \mathrm{C}$, no reaction occurred (entry 3$)$. Raising the reaction temperature to reflux $\left(45^{\circ} \mathrm{C}\right)$ caused a decrease of the yield of $\mathbf{1 h}$ (Table 3, entry 4). On the other hand, using methyl acrylate as a Michael acceptor, only trace amounts of chlorinated product were obtained under similar reaction conditions (Scheme 5).

Scheme 4

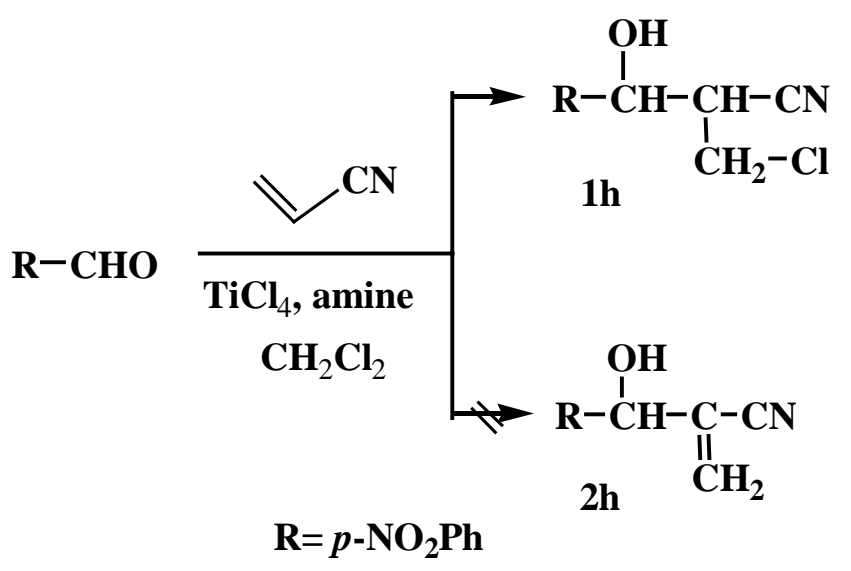

Scheme 5

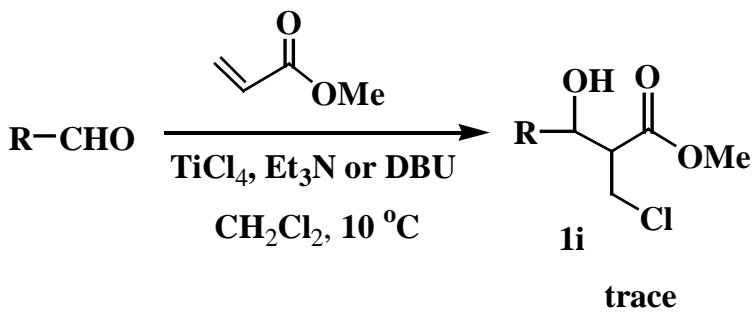

$\mathrm{R}=p-\mathrm{NO}_{2} \mathrm{Ph}$ 
Table 3. Bayliss-Hillman Reaction of p-Nitrobenzaldehyde with Acrylonitrile in the Presence of $\mathrm{TiCl}_{4}$ and $20 \mathrm{~mol} \%$ of Amine as Lewis Base

\begin{tabular}{|c|c|c|c|c|}
\hline Entry & Amine & $\begin{array}{c}\text { Temp } \\
{\left[{ }^{\circ} \mathbf{C}\right]}\end{array}$ & $\begin{array}{c}\text { Time } \\
{[\mathbf{h}]}\end{array}$ & $\begin{array}{c}\text { Yield }^{\text {a) }} \\
{[\%]}\end{array}$ \\
\hline 1 & $\mathrm{Et}_{3} \mathrm{~N}$ & 10 & 5 & 37 \\
2 & $\mathrm{DBU}$ & 10 & 5 & 50 \\
3 & $\mathrm{DBU}$ & -78 & 3 & 0 \\
4 & $\mathrm{DBU}$ & 40 & 3 & 16 \\
\hline \multicolumn{3}{|c}{ a) isolated yield }
\end{tabular}

To the best of our knowledge, this represents a novel Baylis-Hillman reaction system because use of a catalytic amount of amine as a Lewis base has never been reported to date for titanium(IV) chloride promoted Baylis-Hillman reactions. Recently, Aggarwal has reported that using stoichiometric amounts of amine such as DABCO and a catalytic amount of titanium (IV) chloride gave reduced reaction rates, but that use of stoichiometric amounts of amine and a catalytic amount of lanthanide triflates (5 mol\%) gave increased rates in the Baylis-Hillman reaction [7]. Our system shows that using excess amounts of titanium (IV) chloride and catalytic amount of amines, the major reaction products in moderate to high yields are the $\beta$-chlorinated compounds $\mathbf{1}$, which can be readily transformed to the Baylis-Hillman olefin 2. Thus the reaction rate of Baylis-Hillman reaction can be greatly accelerated by means of this reagent system.

We also examined many other metal halides such as $\mathrm{PdCl}_{2}, \mathrm{RhCl}_{3}, \mathrm{Cp}_{2} \mathrm{ZrCl}_{2}, \mathrm{ZrCl}_{4}, \mathrm{AlCl}_{3}, \mathrm{TMSCl}$, $\mathrm{SiCl}_{4}, \mathrm{BF}_{3}, \mathrm{BCl}_{3}$ and found that $\mathrm{BCl}_{3}$ and $\mathrm{ZrCl}_{4}$ also worked as Lewis acids for this reaction, although they are not as effective as $\mathrm{TiCl}_{4}$. For example, we carried out the Baylis-Hillman reaction using $\mathrm{BCl}_{3}$ and $\mathrm{ZrCl}_{4}$ as Lewis acid with $\mathrm{Et}_{3} \mathrm{~N}$ as a Lewis base under the same reaction conditions as those shown in Scheme 1. The syn-chlorinated products can be also obtained (Scheme 6), but this required longer reaction times $(40 \mathrm{~h})$ at $-78^{\circ} \mathrm{C}$. These results are summarized in Table 4.

\section{Scheme 6}

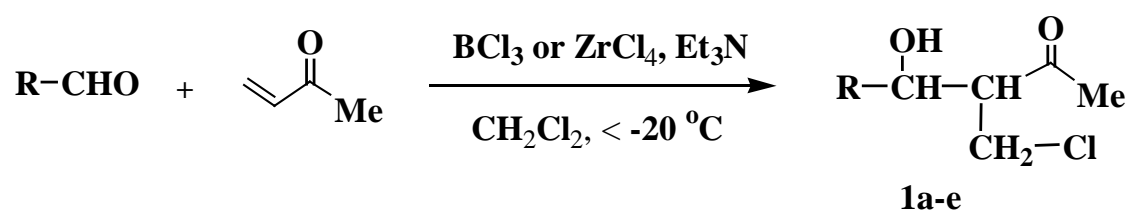


Table 4. Baylis-Hillman Reaction of Aldehydes with Methyl Vinyl Ketone in the Presence of $\mathrm{BCl}_{3}$ (1.4 eq.) or $\mathrm{ZrCl}_{4}\left(1.4 \mathrm{eq}\right.$ ) and $20 \mathrm{~mol} \%$ of $\mathrm{Et}_{3} \mathrm{~N}$

\begin{tabular}{|c|c|c|c|c|c|}
\hline Entry & $\mathbf{R}$ & Lewis acid & $\begin{array}{c}\text { Temp } \\
{\left[{ }^{\circ} \mathbf{C}\right]}\end{array}$ & $\begin{array}{c}\text { Time } \\
{[\mathbf{h}]}\end{array}$ & $\begin{array}{c}\text { Yield }^{\text {a) }} \\
{[\%]}\end{array}$ \\
\hline 1 & $p-\mathrm{NO}_{2}-\mathrm{Ph}$ & $\mathrm{BCl}_{3}$ & -78 & 40 & 64 \\
2 & $m-\mathrm{NO}_{2}-\mathrm{Ph}$ & $\mathrm{BCl}_{3}$ & -78 & 42 & 63 \\
3 & $o-\mathrm{NO}_{2}-\mathrm{Ph}$ & $\mathrm{BCl}_{3}$ & -78 & 42 & 58 \\
4 & $p-\mathrm{CF}_{3}-\mathrm{Ph}$ & $\mathrm{BCl}_{3}$ & -78 & 48 & 42 \\
5 & $\mathrm{Ph}$ & $\mathrm{BCl}_{3}$ & -20 & 48 & 34 \\
6 & $p-\mathrm{Cl}-\mathrm{Ph}$ & $\mathrm{BCl}_{3}$ & -20 & 48 & 45 \\
7 & $p-\mathrm{NO}_{2}-\mathrm{Ph}$ & $\mathrm{ZrCl}_{4}$ & -78 & 48 & 57 \\
8 & $p-\mathrm{Cl}-\mathrm{Ph}$ & $\mathrm{ZrCl}_{4}$ & -78 & 48 & 43 \\
\hline \multicolumn{5}{|r|}{} \\
\hline \multicolumn{5}{|c|}{ a)isolated yields }
\end{tabular}

In Scheme 7, we propose a tentative mechanism to explain the formation of product $\mathbf{1}$. In fact, the reactions of trimethylamine and dimethylamine with titanium (IV) chloride had been investigated by Antler and Laubengayer in 1955 [15a]. Chloride ion was detected although the system was complicated. Based on his findings, Periasamy gave a mechanism for the reaction of tertiary amines with $\mathrm{TiCl}_{4}[15 \mathrm{~b}]$. Recently many crystal structures of $\mathrm{Ti}$ complexes derived from the reaction of $\mathrm{TiCl}_{4}$ with amines have been disclosed including cationic Ti complexes [15c,d,e].

Scheme 7
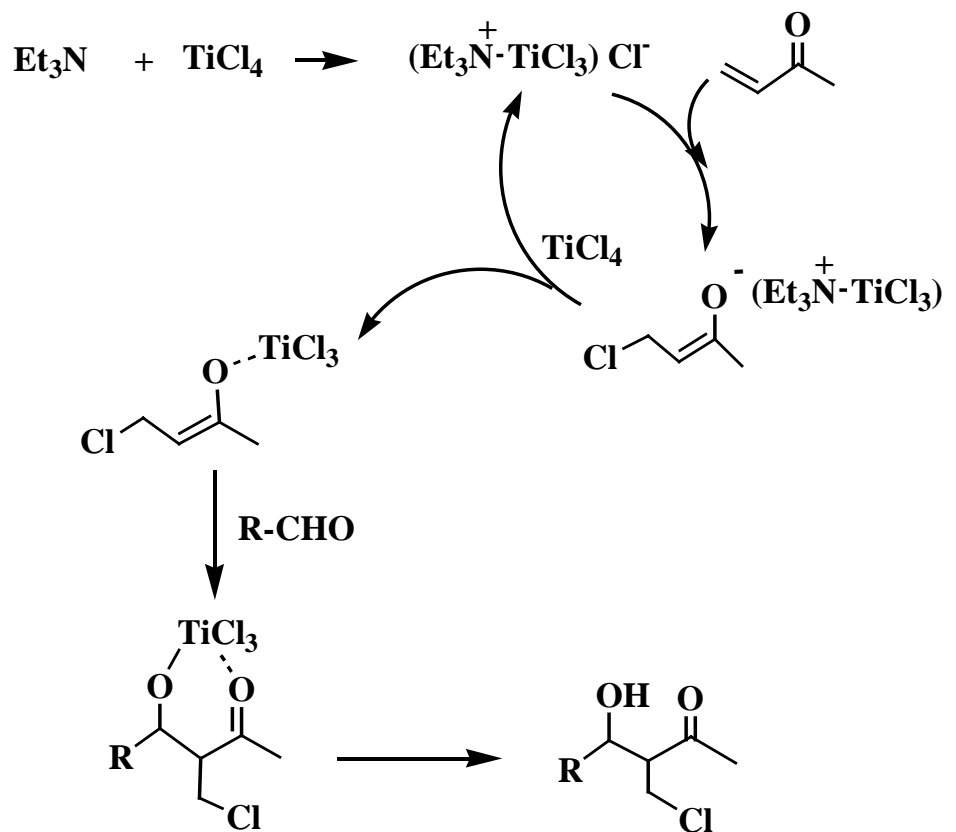<smiles>[R]C(O)C(CCl)C(C)=O</smiles> 
The reaction mechanism proposed in Scheme 7 is based on those previous findings and the results of our own investigations as shown in Table 1 . We believe that amine can strongly coordinate to the Ti metal center of $\mathrm{TiCl}_{4}$ to give an ionic metal complex containing chloride ion. This reaction is related with the attack of chloride ion on the methyl vinyl ketone in a Michael addition fashion (Scheme 7). Using $\mathrm{BCl}_{3}$ or $\mathrm{ZrCl}_{4}$ as a Lewis acid, the reactions would proceed via the same mechanism. Thus, the formation of chlorinated compound $\mathbf{1}$ is a major reaction process in the $\mathrm{TiCl}_{4}, \mathrm{BCl}_{3}$, and $\mathrm{ZrCl}_{4}$ and Lewis base amine promoted Baylis-Hillman reaction.

Figure 2: The chiral Lewis bases used for the Bayliss-Hillman reaction

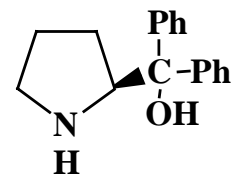

A<smiles>c1ccc(C2OC[C@H]3N[C@@H]4CO[C@@H](c5ccccc5)O[C@@H]4[C@@H]3O2)cc1</smiles>

E<smiles>NC(=S)Nc1ccc2ccccc2c1-c1cccc2ccccc12</smiles>

I<smiles>OC(c1ccccc1)(c1ccccc1)[C@H]1CCCN1Cc1ccccc1</smiles>

B<smiles>CO[C@H]1CC[C@@H](OC)N1</smiles>

C<smiles>COC[C@@H]1CC[C@@H](COC)N1CC(O)(c1ccccc1)c1ccccc1</smiles>

D<smiles></smiles>

F<smiles>NC(=S)Nc1ccc2ccccc2c1-c1c(N)ccc2ccccc12</smiles><smiles>Nc1ccc2ccccc2c1-c1c(N)ccc2ccccc12</smiles>

G<smiles>Nc1ccc2ccccc2c1-c1cccc2ccccc12</smiles><smiles></smiles>

K

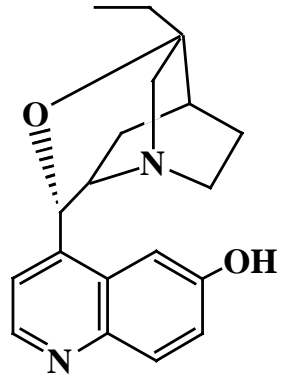

L

We also examined the catalytic enantioselective Baylis-Hillman reaction using chiral amines or aminoalcohols as chiral Lewis bases for this reaction (Scheme 8). The enantiomeric excesses achieved were determined by chiral HPLC analysis of $\mathbf{1 a}$ or $\mathbf{2 a}$ after treating with DBU or $\mathrm{Et}_{3} \mathrm{~N}$. In Figure 2, we 
show the chiral Lewis bases used for this reaction. These chiral ligands (A-L) were either prepared by us according to the known synthetic methods or purchased from Aldrich. For sterically bulky amines, the reaction is relatively slow and longer reaction times are required, but in all cases, the achieved enantiomeric excesses were only about $10 \sim 20 \%$. We believe that this is related to the mechanism shown in Scheme 7 because the reaction is via separated ionic intermediates and the chiral centers are far away from the aldol reaction center. These results partially support our proposed reaction mechanism (Scheme 7).

\section{Scheme 8}
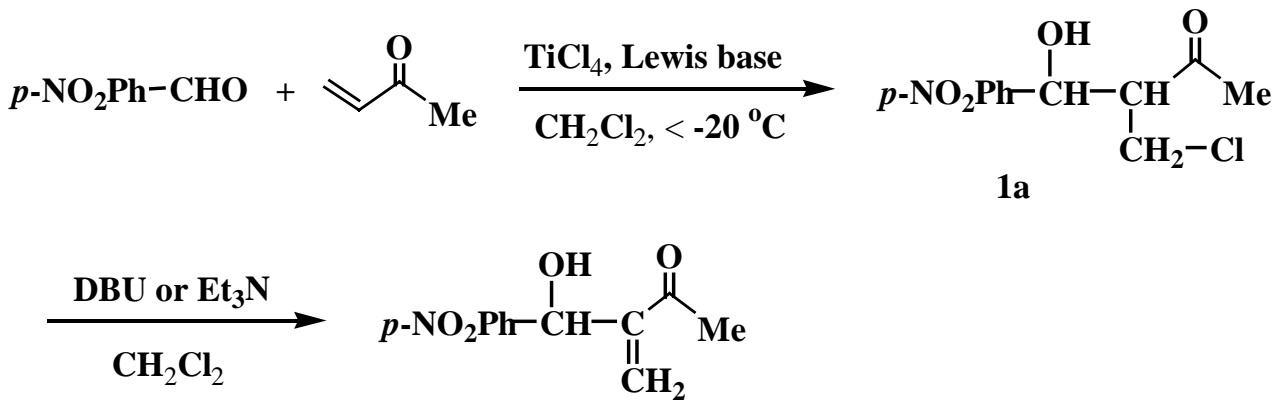

2a

On the other hand, by carrying out this reaction at room temperature (about $20^{\circ} \mathrm{C}$ ), we confirmed that the elimination product 3 was the only product under the same reaction conditions (Scheme 9, Table 5, entries 3-10).

Scheme 9

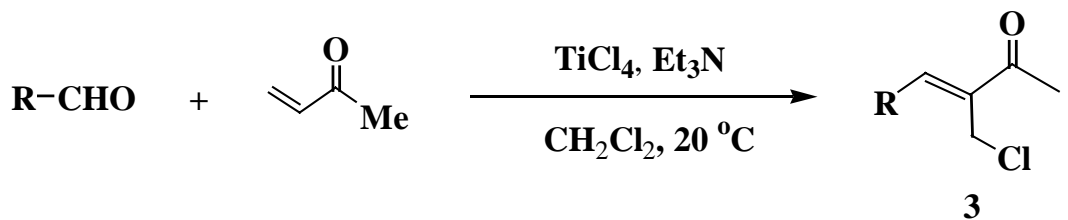

a: $\mathrm{R}=p-\mathrm{NO}_{2} \mathrm{Ph}, \mathrm{b}: \mathrm{R}=o-\mathrm{NO}_{2} \mathrm{Ph}, \mathrm{c}: \mathrm{R}=\boldsymbol{p}-\mathrm{CF}_{3} \mathrm{Ph}, \mathrm{d}: \mathrm{R}=\boldsymbol{p}-\mathrm{CIPh}$, e: $\mathrm{R}=m$-FPh; f: $\mathrm{R}=p$-EtPh; $\mathrm{g}: \mathrm{R}=\mathrm{Ph} ; \mathrm{h}: \mathrm{R}=\mathrm{Me}\left(\mathrm{CH}_{2}\right)_{8}$.

Table 5. Bayliss-Hillman Reaction of Aldehydes with Methyl Vinyl Ketone in the Presence of 1.4 eq. of $\mathrm{TiCl}_{4}$ and 0.20 eq. of $\mathrm{Et}_{3} \mathrm{~N}$ at Room Temperature

\begin{tabular}{|c|c|c|c|}
\hline Entry & $\mathbf{R}$ & Time $[\mathbf{h}]$ & $\begin{array}{c}\text { Yield }^{\text {a) }}(\boldsymbol{\%}) \\
\mathbf{3}\end{array}$ \\
\hline 1 & $p-\mathrm{NO}_{2}-\mathrm{Ph}$ & 6 & $30^{\mathrm{b})}$ \\
2 & $p-\mathrm{NO}_{2}-\mathrm{Ph}$ & 6 & 50 \\
3 & $p-\mathrm{NO}_{2}-\mathrm{Ph}$ & 24 & 92 \\
\hline
\end{tabular}




\begin{tabular}{|c|c|c|c|}
\hline 4 & $o-\mathrm{NO}_{2}-\mathrm{Ph}$ & 24 & 86 \\
5 & $p-\mathrm{CF}_{3}-\mathrm{Ph}$ & 24 & 87 \\
6 & $p-\mathrm{Cl}-\mathrm{Ph}$ & 24 & 75 \\
7 & $m-\mathrm{F}-\mathrm{Ph}$ & 24 & 82 \\
8 & $p-\mathrm{Et}-\mathrm{Ph}$ & 36 & 60 \\
9 & $\mathrm{Ph}$ & 24 & 77 \\
10 & $\mathrm{CH}_{3}\left(\mathrm{CH}_{2}\right)_{8}$ & 24 & 50 \\
\hline
\end{tabular}

This reaction was first disclosed by $\mathrm{Li}$ and coworkers. They reported that in the presence of stoichiometric or nonstoichiometric TiX 4 , compound $\mathbf{3}$ could be formed in its Z-configuration [12]. Later we also reported that 3 could be exclusively obtained in the $\mathrm{TiCl}_{4}$ and chalcogenide promoted BaylisHillman reaction at room temperature $\left(20^{\circ} \mathrm{C}\right)$ [16]. The Z-configuration has been confirmed by X-ray analysis (Figure 3) [16].

Figure 3: Crystal Structure of 3a

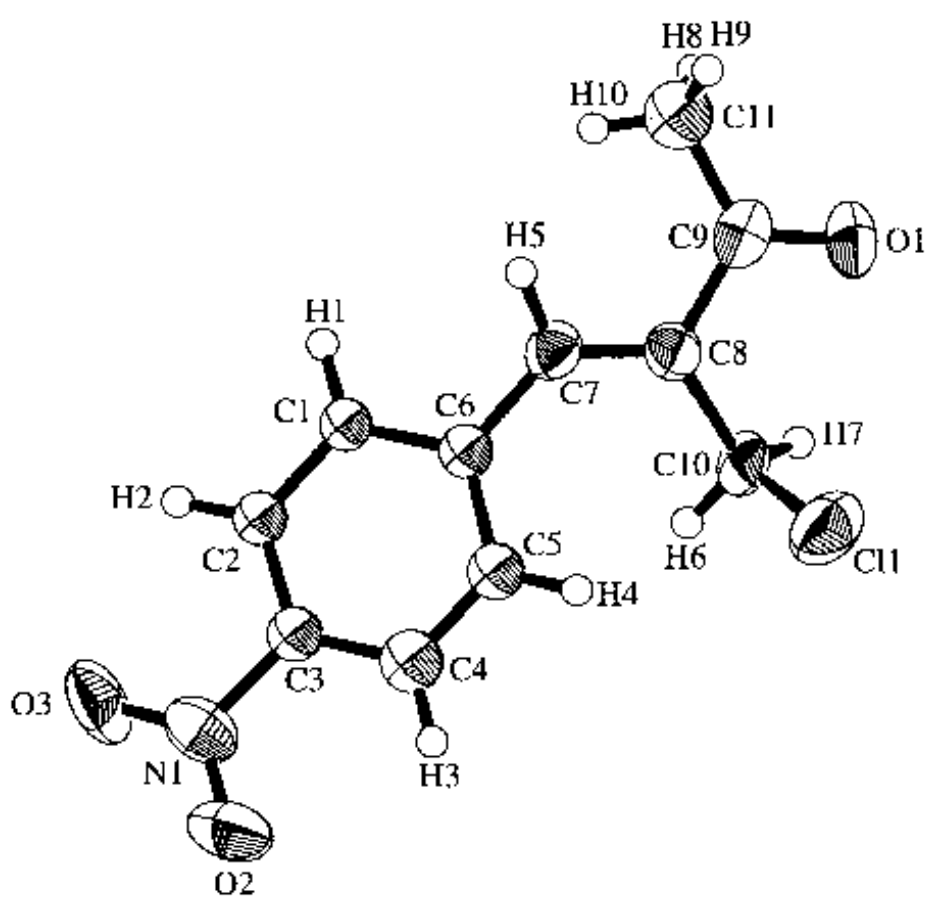

We now wish to report that in the initial reaction stage, the presence of Lewis base can still significantly speed up this reaction (Table 5 , entry 1 and 2). In order to clarify the formation of $\mathbf{3}$, we treated $\mathbf{1 a}$ and $\mathbf{2 a}$ directly with $\mathrm{TiCl}_{4}$ in dichloromethane at room temperature. We found that $\mathbf{1 a}$ can be transformed to $\mathbf{3 a}$ within $6 \mathrm{~h}$, whereas the reaction of $\mathbf{2 a}$ with $\mathrm{TiCl}_{4}$ was much slower (Scheme 10). These 
results strongly suggest that $\mathbf{3 a}$ is derived directly from $\mathbf{1 a}$ formed first in the reaction. Thus, we conclude that, at room temperature, the chlorinated products $\mathbf{1}$ could be formed either in the absence or in the presence of Lewis base, but they are rapidly transformed to the elimination product $\mathbf{3}$ exclusively.

\section{Scheme 10}
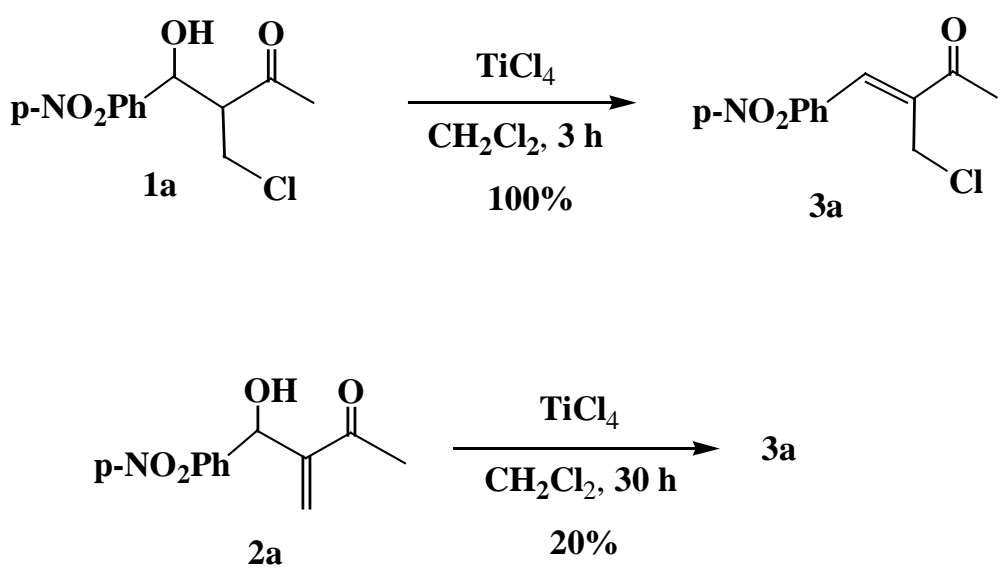

\section{Conclusions}

We have found that $\mathrm{TiCl}_{4}, \mathrm{BCl}_{3}$ or $\mathrm{ZrCl}_{4}$ and amine promoted Baylis-Hillman reaction is a very efficient reaction system for producing chlorinated compounds $\mathbf{1}$. The amine compounds are good Lewis bases and $\mathrm{TiCl}_{4}, \mathrm{BCl}_{3}$ and $\mathrm{ZrCl}_{4}$ are good Lewis acids for this reaction. The reaction temperatures, the amount of Lewis acid, and the amount of Lewis base can drastically affect the reaction products and reaction rates. The relative activities of different Lewis acids for this reaction are $\mathrm{TiCl}_{4}>\mathrm{BCl}_{3}>\mathrm{ZrCl}_{4}$ and the best combination of Lewis acid and Lewis base for this reaction is $\mathrm{TiCl}_{4}(1.4 \mathrm{eq})$ with $\mathrm{NEt}_{3}(0.2 \mathrm{eq})$. The relative configuration of $\mathbf{1}$ was not affected by the Lewis acids $\left(\mathrm{TiCl}_{4}, \mathrm{BCl}_{3}\right.$ or $\mathrm{ZrCl}_{4}$ ) used at all. The reaction was initiated by chloride ion attacking at the Michael acceptor of the $\alpha, \beta$-unsaturated ketone. The chloride ion was produced by coordination of Lewis bases ( $\mathrm{NEt}_{3}$ ) to Lewis acids such as $\mathrm{TiCl}_{4}, \mathrm{BCl}_{3}$, and $\mathrm{ZrCl}_{4}$. Undoubtedly compound $\mathbf{3}$ was derived mainly from $\mathbf{1}$. Efforts are underway to elucidate the full mechanistic details of this reaction and to disclose the scope and limitations of this reaction. Work along this line are currently in progress.

\section{Acknowledgements}

The State Key Project for Basic Research has provided financial support (Project 973; No. G2000048007) as has the National Natural Sciences Foundation of China. We also thank Inoue Photochirogenesis Project for supplying chemical reagents. 


\section{Experimental Section}

\section{General}

Melting points are uncorrected. ${ }^{1} \mathrm{H}$ - and ${ }^{13} \mathrm{C}-\mathrm{NMR}$ spectra were recorded on a Bruker AMX-300 spectrometer at $300 \mathrm{MHz}$ and $75 \mathrm{MHz}$, respectively. Mass spectra were recorded by the EI method and HRMS was measured by a Finnigan MA+ mass spectrometer. Organic solvents used were dried by standard methods when necessary. All solid compounds reported in this paper gave satisfactory CHN microanalyses. Commercially obtained reagents were used without further purification. All reactions were monitored by TLC with Huanghai $\mathrm{GF}_{254}$ silica gel coated plates. Flash Column Chromatography was carried out using 300-400 mesh silica gel at increased pressure.

Typical procedure for the preparation of compounds 1a-h and 2a: 3-(Chloromethyl)-4-hydroxy-4-(4'nitrophenyl)-2-butanone (1a).

To a solution of triethylamine $(10.1 \mathrm{mg}, 0.1 \mathrm{mmol}, 14.0 \mu \mathrm{L})$ in $\mathrm{CH}_{2} \mathrm{Cl}_{2}(1.3 \mathrm{~mL})$ was added titanium tetrachloride $(0.7 \mathrm{~mL}, 0.7 \mathrm{mmol})$ at $-78{ }^{\circ} \mathrm{C}$. After stirring for $5 \mathrm{~min}$, a solution of $p$-nitrobenzaldehyde (75.5 mg, $0.5 \mathrm{mmol})$ in $\mathrm{CH}_{2} \mathrm{Cl}_{2}(1.0 \mathrm{~mL})$ and methyl vinyl ketone (105.0 mg, $\left.1.5 \mathrm{mmol}, 123.0 \mu \mathrm{L}\right)$ were added into the reaction solution at $-78{ }^{\circ} \mathrm{C}$, respectively. The reaction mixture was kept for $12 \mathrm{~h}$ at $-78{ }^{\circ} \mathrm{C}$. The reaction was quenched by addition of saturated aqueous $\mathrm{NaHCO}_{3}$ solution $(1.0 \mathrm{~mL})$. After filtration, the filtrate was extracted with $\mathrm{CH}_{2} \mathrm{Cl}_{2}\left(5.0 \mathrm{~mL}\right.$ x 2) and dried over anhydrous $\mathrm{MgSO}_{4}$. The solvent was removed under reduced pressure and the residue was purified by a flash chromatography (silicagel, eluent 1:4 ethyl acetate/petroleum ether) to give compound $\mathbf{1 a}(105.0 \mathrm{mg}, 81 \%)$ as a colorless solid, mp 90-91 ${ }^{\circ} \mathrm{C}$; IR (KBr) v $1720 \mathrm{~cm}^{-1}$; ${ }^{1} \mathrm{H}-\mathrm{NMR}\left(\mathrm{CDCl}_{3}, 300 \mathrm{MHz}\right): \delta 2.20(3 \mathrm{H}, \mathrm{s}, \mathrm{Me}), 2.93(1 \mathrm{H}, \mathrm{br} . \mathrm{s}, \mathrm{OH}), 3.22-$ $3.38(1 \mathrm{H}, \mathrm{m}), 3.67(1 \mathrm{H}, \mathrm{dd}, J 11.3,4.0 \mathrm{~Hz}), 3.89(1 \mathrm{H}, \mathrm{dd}, J 11.3,9.2 \mathrm{~Hz}), 5.11(1 \mathrm{H}, \mathrm{d}, J 5.6 \mathrm{~Hz}), 7.56(2 \mathrm{H}$, d, J $8.6 \mathrm{~Hz}, \mathrm{Ar}), 8.25(2 \mathrm{H}, \mathrm{d}, J 8.6 \mathrm{~Hz}, \mathrm{Ar})$; MS (EI) m/e $258\left(\mathrm{MH}^{+}, 0.60\right), 208\left(\mathrm{M}^{+}-49,60\right), 71\left(\mathrm{M}^{+}-186\right.$, 100); Anal. Found: C, 51.64; H, 4.94; N, 5.35\%. $\mathrm{C}_{11} \mathrm{H}_{12} \mathrm{ClNO}_{4}$ requires $\mathrm{C}, 51.27 ; \mathrm{H}, 4.69 ; \mathrm{N}, 5.44 \%$.

\section{3-(Chloromethyl)-4-hydroxy-4-(3'-nitrophenyl)-2-butanone (1b).}

Colorless oil, $113 \mathrm{mg}(88 \%)$; IR (KBr): $v 1720 \mathrm{~cm}^{-1}(\mathrm{C}=\mathrm{O}) ;{ }^{1} \mathrm{H}-\mathrm{NMR}\left(\mathrm{CDCl}_{3}, 300 \mathrm{MHz}\right): \delta 2.20(3 \mathrm{H}$, s, Me), 2.95 (1H, br. s, OH), 3.20-3.35 (1H, m), $3.66(1 \mathrm{H}, \mathrm{dd}, J 11.3,3.9 \mathrm{~Hz}), 3.89$ (1H, dd, J 11.3, 9.3 $\mathrm{Hz}), 5.13(1 \mathrm{H}, \mathrm{d}, J 5.6 \mathrm{~Hz}), 7.54(1 \mathrm{H}, \mathrm{t}, J 7.9 \mathrm{~Hz}, \mathrm{Ar}), 7.69(1 \mathrm{H}, \mathrm{d}, J 7.6 \mathrm{~Hz}, \mathrm{Ar}), 8.2(1 \mathrm{H}, \mathrm{d}, J 7.6 \mathrm{~Hz}$, Ar), 8.25 (1H, s, Ar); MS (EI) m/e $257\left(\mathrm{M}^{+}, 0.60\right), 208\left(\mathrm{M}^{+}-49,60\right), 71\left(\mathrm{M}^{+}-186,100\right)$; [HRMS (EI) $\mathrm{m} / z$ 239.0353 $\left(\mathrm{M}^{+}-\mathrm{H}_{2} \mathrm{O}\right) \cdot \mathrm{C}_{11} \mathrm{H}_{10} \mathrm{O}_{3} \mathrm{NCl}$ requires $\left.M-H_{2} O, 239.0349\right]$.

3-(Chloromethyl)-4-hydroxy-4-(4'-trifluoromethylphenyl)-2-butanone (1c).

Colorless oil, $112 \mathrm{mg}(80 \%)$; IR(KBr) $\vee 1720 \mathrm{~cm}^{-1}(\mathrm{C}=\mathrm{O}) ;{ }^{1} \mathrm{H}-\mathrm{NMR}\left(\mathrm{CDCl}_{3}, 300 \mathrm{MHz}\right) \delta 2.13(3 \mathrm{H}, \mathrm{s}$, Me), $2.65(1 \mathrm{H}$, br. s, OH), 3.22-3.37 $(1 \mathrm{H}, \mathrm{m}), 3.70(1 \mathrm{H}, \mathrm{dd}, J 10.2,3.9 \mathrm{~Hz}), 3.89(1 \mathrm{H}, \mathrm{dd}, J 10.2,10.2$ 
$\mathrm{Hz}), 5.02(1 \mathrm{H}, \mathrm{d}, J 6.1 \mathrm{~Hz}), 7.37(2 \mathrm{H}, \mathrm{d}, J 8.0 \mathrm{~Hz}, \mathrm{Ar}), 7.64(2 \mathrm{H}, \mathrm{d}, J 8.0 \mathrm{~Hz}, \mathrm{Ar}) ; \mathrm{MS}(\mathrm{EI}) \mathrm{m} / \mathrm{e} 280\left(\mathrm{M}^{+}\right.$, 0.45), $243\left(\mathrm{M}^{+}-37,40\right), 43\left(\mathrm{M}^{+}-237,100\right)$; [HRMS (EI) $\mathrm{m} / z 262.0377\left(\mathrm{M}^{+}-\mathrm{H}_{2} \mathrm{O}\right) . \mathrm{C}_{12} \mathrm{H}_{10} \mathrm{OClF}_{3}$ requires $\left.\mathrm{M}-\mathrm{H}_{2} \mathrm{O}, 262.0372\right]$.

3-(Chloromethyl)-4-hydroxy-4-phenyl-2-butanone (1d).

Colorless oil: $85 \mathrm{mg}(80 \%)$; a $\mathrm{IR}(\mathrm{KBr}) \vee 1720 \mathrm{~cm}^{-1}(\mathrm{C}=\mathrm{O}) ;{ }^{1} \mathrm{H}-\mathrm{NMR}\left(\mathrm{CDCl}_{3}, 300 \mathrm{MHz}\right) \delta 2.02(3 \mathrm{H}$, s, Me), $2.45(1 \mathrm{H}$, br. s, OH), 3.22-3.37 (1H, m), $3.78(1 \mathrm{H}, \mathrm{dd}, J$ 10.7, $3.8 \mathrm{~Hz}), 3.90(1 \mathrm{H}, \mathrm{dd}, J 10.4,10.4$ $\mathrm{Hz}), 4.84(1 \mathrm{H}, \mathrm{d}, J 6.9 \mathrm{~Hz}), 7.10-7.32(5 \mathrm{H}, \mathrm{m}, \mathrm{Ar})$; MS (EI) m/e $212\left(\mathrm{M}^{+}, 1.05\right), 163\left(\mathrm{M}^{+}-49,60\right), 107$ $\left(\mathrm{M}^{+}-105,100\right)$; [HRMS (EI) $m / z 212.0594\left(\mathrm{M}^{+}\right) . \mathrm{C}_{11} \mathrm{H}_{13} \mathrm{O}_{2} \mathrm{Cl}$ requires $\left.M, 212.0604\right]$.

3-(Chloromethyl)-4-hydroxy-4-(4'-ethylphenyl)-2-butanone (1e).

Colorless solid: $87 \mathrm{mg}(72 \%) ;$ mp 69-71 ${ }^{\circ} \mathrm{C}$; $\mathrm{IR}(\mathrm{KBr}) \vee 1720 \mathrm{~cm}^{-1}(\mathrm{C}=\mathrm{O}) ;{ }^{1} \mathrm{H}-\mathrm{NMR}\left(\mathrm{CDCl}_{3}, 300\right.$ MHz) $\delta 1.21(3 \mathrm{H}, \mathrm{t}, J 7.7 \mathrm{~Hz}), 2.02(3 \mathrm{H}, \mathrm{s}, \mathrm{Me}), 2.15(1 \mathrm{H}, \mathrm{br} . \mathrm{s}, \mathrm{OH}), 2.63(2 \mathrm{H}, \mathrm{q}, J 7.7 \mathrm{~Hz}), 3.22-3.37$ $(1 \mathrm{H}, \mathrm{m}), 3.80(1 \mathrm{H}, \mathrm{dd}, J 10.7,3.8 \mathrm{~Hz}), 3.90(1 \mathrm{H}, \mathrm{dd}, J 10.7,10.7 \mathrm{~Hz}), 4.82(1 \mathrm{H}, \mathrm{d}, J 7.2 \mathrm{~Hz}), 7.10-7.32$ (4H, m, Ar); MS (EI) m/e $222\left(\mathrm{M}^{+}-18,1.20\right), 191\left(\mathrm{M}^{+}-49,20\right), 135\left(\mathrm{M}^{+}-105,100\right)$; [HRMS (EI) $\mathrm{m} / \mathrm{z}$ $240.0908\left(\mathrm{M}^{+}\right) . \mathrm{C}_{13} \mathrm{H}_{17} \mathrm{O}_{2} \mathrm{Cl}$ requires $\left.M, 240.0917\right]$.

3-(Chloromethyl)-4-hydroxy-4-(4'-chlorophenyl)-2-butanone (1f).

Colorless oil: $86 \mathrm{mg}(70 \%)$; a; $\mathrm{IR}(\mathrm{KBr}) \vee 1720 \mathrm{~cm}^{-1}(\mathrm{C}=\mathrm{O}) ;{ }^{1} \mathrm{H}-\mathrm{NMR}\left(\mathrm{CDCl}_{3}, 300 \mathrm{MHz}\right) \delta 2.0(3 \mathrm{H}, \mathrm{s}$, Me), $2.50(1 \mathrm{H}$, br. s, OH), 3.20-3.32 (1H, m), $3.75(1 \mathrm{H}, \mathrm{dd}, J$ 10.7, $3.8 \mathrm{~Hz}), 3.87(1 \mathrm{H}, \mathrm{dd}, J$ 10.7, 10.7 $\mathrm{Hz}), 4.82(1 \mathrm{H}, \mathrm{d}, J 6.7 \mathrm{~Hz}), 7.10-7.32(4 \mathrm{H}, \mathrm{m}, \mathrm{Ar})$; MS (EI) m/e $246\left(\mathrm{M}^{+}, 1.20\right), 121\left(\mathrm{M}^{+}-125,20\right), 91$ $\left(\mathrm{M}^{+}-155,100\right)$; [HRMS (EI) $m / z 246.0210\left(\mathrm{M}^{+}\right) . \mathrm{C}_{11} \mathrm{H}_{12} \mathrm{O}_{2} \mathrm{Cl}_{2}$ requires $\left.M, 246.0214\right]$.

\section{3-(Chloromethyl)-4-hydroxy-4-butyl-2-butanone (1g).}

Colorless oil: $43 \mathrm{mg}(45 \%)$; a $\mathrm{IR}(\mathrm{KBr}) \vee 1720 \mathrm{~cm}^{-1}(\mathrm{C}=\mathrm{O}) ;{ }^{1} \mathrm{H}-\mathrm{NMR}\left(\mathrm{CDCl}_{3}, 300 \mathrm{MHz}\right) \delta 0.89(3 \mathrm{H}$, t, J 7.1 Hz), 1.10-1.60 (6H, m), $2.08(1 \mathrm{H}, \mathrm{s}, \mathrm{OH}), 2.34(3 \mathrm{H}, \mathrm{s}, \mathrm{Me}), 3.0-3.10(1 \mathrm{H}, \mathrm{m}), 3.60-3.85(3 \mathrm{H}, \mathrm{m})$; MS (EI) m/e $192\left(\mathrm{M}^{+}, 0.80\right), 155\left(\mathrm{M}^{+}-37,30\right), 43\left(\mathrm{M}^{+}-149,100\right)$; [HRMS (EI) $\mathrm{m} / z 192.0908\left(\mathrm{M}^{+}\right)$. $\mathrm{C}_{9} \mathrm{H}_{17} \mathrm{O}_{2} \mathrm{Cl}$ requires $\left.M, 192.0917\right]$.

Preparation of 2-(chloromethyl)-3-hydroxy-3-(4'-nitrophenyl)-propionitrile (1h).

Colorless oil: $45 \mathrm{mg}(37 \%)$; IR(KBr) $\vee 1720 \mathrm{~cm}^{-1}(\mathrm{C}=\mathrm{O}) ;{ }^{1} \mathrm{H}$ NMR $\left(\mathrm{CDCl}_{3}, 300 \mathrm{MHz}\right) \delta 2.50(1 \mathrm{H}, \mathrm{s}$, $\mathrm{OH}), 3.28(1 \mathrm{H}, \mathrm{q}, J 6.1 \mathrm{~Hz}), 3.70(1 \mathrm{H}, \mathrm{dd}, J 11.3,4.5 \mathrm{~Hz}), 3.96(1 \mathrm{H}, \mathrm{dd}, J 11.3,5.8 \mathrm{~Hz}), 7.67(2 \mathrm{H}, \mathrm{d}, J 8.3$ $\mathrm{Hz}), 8.28(2 \mathrm{H}, \mathrm{d}, J 8.3 \mathrm{~Hz})$; MS (EI) m/e $240\left(\mathrm{M}^{+}, 38.75\right), 205\left(\mathrm{M}^{+}-35,30\right), 152\left(\mathrm{M}^{+}-149,100\right)$; [HRMS (EI) $m / z 240.0310\left(\mathrm{M}^{+}\right) . \mathrm{C}_{10} \mathrm{H}_{9} \mathrm{ClN}_{2} \mathrm{O}_{3}$ requires $M, 240.0302$ ]. 
3-[(4'-nitrophenyl)hydroxymethyl]-3-buten-2-one (2a).

A known compound [9]. Its physical data was comparable to that reported in literature: $\mathrm{mp}$ 66-68 ${ }^{\circ} \mathrm{C}$; ${ }^{1} \mathrm{H}$-NMR $\left(\mathrm{CDCl}_{3}, 300 \mathrm{MHz}\right)$ d 2.36 (3H, s, Me), 3.26 (1H, br. s, OH), $5.68(1 \mathrm{H}, \mathrm{s}), 6.05(1 \mathrm{H}, \mathrm{s}), 6.28$ $(1 \mathrm{H}, \mathrm{s}), 7.56(2 \mathrm{H}, \mathrm{d}, J 8.6 \mathrm{~Hz}, \mathrm{Ar}), 8.19(2 \mathrm{H}, \mathrm{d}, J 8.6 \mathrm{~Hz}, \mathrm{Ar})$.

Typical Procedure for the Preparation of 3-(Chloromethyl)-4-(4'-nitrophenyl)-3-buten-2-one (3a).

To a solution of triethylamine $(10.1 \mathrm{mg}, 0.1 \mathrm{mmol}, 14.0 \mu \mathrm{L})$ in $\mathrm{CH}_{2} \mathrm{Cl}_{2}(1.3 \mathrm{~mL})$ was added $1.0 \mathrm{~N}$ titanium tetrachloride $(0.7 \mathrm{~mL}, 0.7 \mathrm{mmol})$ in $\mathrm{CH}_{2} \mathrm{Cl}_{2}$ at room temperature $\left(20{ }^{\circ} \mathrm{C}\right)$. After stirring for $5 \mathrm{~min}$, a solution of $p$-nitrobenzaldehyde $(76 \mathrm{mg}, 0.5 \mathrm{mmol})$ in $\mathrm{CH}_{2} \mathrm{Cl}_{2}(1.0 \mathrm{~mL})$ and methyl vinyl ketone (105 $\mathrm{mg}, 1.5 \mathrm{mmol}, 123 \mu \mathrm{L}$ ) were added into the reaction solution at room temperature. The reaction mixture was kept for $24 \mathrm{~h}$ at room temperature. The reaction was quenched by addition of saturated aqueous $\mathrm{NaHCO}_{3}$ solution $(1.0 \mathrm{~mL})$. After filtration, the filtrate was extracted with $\mathrm{CH}_{2} \mathrm{Cl}_{2}(5.0 \mathrm{~mL} \times 2)$ and dried over anhydrous $\mathrm{MgSO}_{4}$. The solvent was removed under reduced pressure and the residue was purified by flash silica gel chromatography to give compound 3a (110 mg, 92\%) as a colorless solid (eluent: ethyl acetate/petroleum ether=1/8): $\mathrm{mp} 134-136{ }^{\circ} \mathrm{C} ; \mathrm{IR}(\mathrm{KBr}) \vee 1640 \mathrm{~cm}^{-1}(\mathrm{C}=\mathrm{O}) ;{ }^{1} \mathrm{H}-\mathrm{NMR}\left(\mathrm{CDCl}_{3}, 300 \mathrm{~Hz}\right) \delta$ $2.55(3 \mathrm{H}, \mathrm{s}, \mathrm{Me}), 4.38\left(2 \mathrm{H}, \mathrm{s}, \mathrm{CH}_{2}\right), 7.69(1 \mathrm{H}, \mathrm{s}), 7.75(2 \mathrm{H}, \mathrm{d}, J 8.6 \mathrm{~Hz}, \mathrm{Ar}), 8.35$ (2H, d, J 8.6 Hz, Ar); MS (EI) m/e 239 ( $\left.\mathrm{M}^{+}, 0.40\right), 222\left(\mathrm{M}^{+}-17,40\right), 115\left(\mathrm{M}^{+}-124,100\right)$; [Found: C, 54.94; H, 3.92; N, 5.87\%. $\mathrm{C}_{11} \mathrm{H}_{10} \mathrm{ClNO}_{3}$ requires $\left.\mathrm{C}, 55.13 ; \mathrm{H}, 4.21 ; \mathrm{N}, 5.84 \%\right]$.

3-(Chloromethyl)-4-(2'-nitrophenyl)-3-buten-2-one (3b).

A colorless solid : $103 \mathrm{mg}(86 \%)$; mp 120-122 ${ }^{\circ} \mathrm{C}$; IR(KBr) v $1640 \mathrm{~cm}^{-1}(\mathrm{C}=\mathrm{O}) ;{ }^{1} \mathrm{H}-\mathrm{NMR}\left(\mathrm{CDCl}_{3}\right.$, $300 \mathrm{MHz}) \delta 2.52(3 \mathrm{H}, \mathrm{s}, \mathrm{Me}), 4.23\left(2 \mathrm{H}, \mathrm{s}, \mathrm{CH}_{2}\right), 7.64(1 \mathrm{H}, \mathrm{td}, J 6.4,1.5 \mathrm{~Hz}, \mathrm{Ar}), 7.72(1 \mathrm{H}, \mathrm{d}, J 6.7 \mathrm{~Hz}$, Ar), $7.80(1 \mathrm{H}, \mathrm{t}, J 7.5 \mathrm{~Hz}, \mathrm{Ar}), 8.02(1 \mathrm{H}, \mathrm{s}), 8.27$ (1H, d, $7.5 \mathrm{~Hz}, \mathrm{Ar})$; MS (EI) m/e $239\left(\mathrm{M}^{+}, 60\right), 222$ $\left(\mathrm{M}^{+}-17,50\right), 115\left(\mathrm{M}^{+}-124,50\right), 43\left(\mathrm{M}^{+}-196,100\right)$; [HRMS (EI) $m / z 239.0351\left(\mathrm{M}^{+}\right) . \mathrm{C}_{11} \mathrm{H}_{10} \mathrm{ClNO}_{3}$ requires $M, 239.0349]$.

3-(Chloromethyl)-4-(4'-trifluoromethylphenyl)-3-buten-2-one (3c).

A colorless solid: $114 \mathrm{mg}(87 \%)$; $\mathrm{mp} 43-45{ }^{\circ} \mathrm{C}$; IR (KBr) v $1640 \mathrm{~cm}^{-1}(\mathrm{C}=\mathrm{O}) ;{ }^{1} \mathrm{H}-\mathrm{NMR}\left(\mathrm{CDCl}_{3}, 300\right.$ $\mathrm{MHz}) \delta 2.54(3 \mathrm{H}, \mathrm{s}, \mathrm{Me}), 4.39\left(2 \mathrm{H}, \mathrm{s}, \mathrm{CH}_{2}\right), 7.70(1 \mathrm{H}, \mathrm{s}), 7.60-7.76(4 \mathrm{H}, \mathrm{m}, \mathrm{Ar})$; MS (EI) m/e $262\left(\mathrm{M}^{+}\right.$, 100), $193\left(\mathrm{M}^{+}-69,70\right), 183\left(\mathrm{M}^{+}-79,50\right), 115\left(\mathrm{M}^{+}-147,40\right)$; [HRMS (EI) $m / z, 262.0381\left(\mathrm{M}^{+}\right) . \mathrm{C}_{12} \mathrm{H}_{10} \mathrm{ClF}_{3} \mathrm{O}$ requires $M, 262.0372]$.

Preparation of 3-(chloromethyl)-4-(4'-chlorophenyl)-3-buten-2-one (3d).

A colorless solid: $86 \mathrm{mg}(75 \%)$; mp 87-89 ${ }^{\circ} \mathrm{C}$; IR (KBr) $\vee 1640 \mathrm{~cm}^{-1}(\mathrm{C}=\mathrm{O}) ;{ }^{1} \mathrm{H}-\mathrm{NMR}\left(\mathrm{CDCl}_{3}, 300\right.$ $\mathrm{MHz}) \delta 2.51(3 \mathrm{H}, \mathrm{s}, \mathrm{Me}), 4.42\left(2 \mathrm{H}, \mathrm{s}, \mathrm{CH}_{2}\right), 7.46(2 \mathrm{H}, \mathrm{d}, J 8.6 \mathrm{~Hz}), 7.54(2 \mathrm{H}, \mathrm{d}, J 8.6 \mathrm{~Hz}), 7.69(1 \mathrm{H}, \mathrm{s})$; 
MS (EI) m/e $228\left(\mathrm{M}^{+}, 20\right), 193\left(\mathrm{M}^{+}-35,40\right), 149\left(\mathrm{M}^{+}-79,40\right), 115\left(\mathrm{M}^{+}-113,40\right), 43\left(\mathrm{M}^{+}-185,100\right)$; [HRMS (EI) $m / z 228.0110\left(\mathrm{M}^{+}\right) . \mathrm{C}_{11} \mathrm{H}_{10} \mathrm{Cl}_{2} \mathrm{O}$ requires $M, 228.0109$ ].

Preparation of 3-(chloromethyl)-4-(3'-fluorophenyl)-3-buten-2-one (3e).

This compound was prepared in the same manner as that described above: $87 \mathrm{mg}(82 \%)$; a colorless solid; mp 63-64 ${ }^{\circ} \mathrm{C}$; IR $(\mathrm{KBr}) \vee 1640 \mathrm{~cm}^{-1}(\mathrm{C}=\mathrm{O}) ;{ }^{1} \mathrm{H}-\mathrm{NMR}\left(\mathrm{CDCl}_{3}, 300 \mathrm{MHz}\right) \delta 2.51(3 \mathrm{H}, \mathrm{s}, \mathrm{Me}), 4.42$ $\left(2 \mathrm{H}, \mathrm{s}, \mathrm{CH}_{2}\right), 7.10-7.50(4 \mathrm{H}, \mathrm{m}, \mathrm{Ar}), 7.69(1 \mathrm{H}, \mathrm{s})$; MS (EI) m/e $212\left(\mathrm{M}^{+}, 15\right), 177\left(\mathrm{M}^{+}-35,40\right), 99\left(\mathrm{M}^{+}-\right.$ 113, 40), $43\left(\mathrm{M}^{+}-169,100\right)$; [HRMS (EI) $m / z 212.0411\left(\mathrm{M}^{+}\right) . \mathrm{C}_{11} \mathrm{H}_{10} \mathrm{ClFO}$ requires $\left.M, 212.0404\right]$.

Preparation of 3-(chloromethyl)-4-(4'-ethylphenyl)-3-buten-2-one (3f).

This compound was prepared in the same manner as that described above: $67 \mathrm{mg}(60 \%)$; a colorless oil; IR $(\mathrm{KBr}) \vee 1640 \mathrm{~cm}^{-1}(\mathrm{C}=\mathrm{O}) ;{ }^{1} \mathrm{H}-\mathrm{NMR}\left(\mathrm{CDCl}_{3}, 300 \mathrm{MHz}\right) \delta 1.28(3 \mathrm{H}, \mathrm{t}, J 7.1 \mathrm{~Hz}), 2.51(3 \mathrm{H}, \mathrm{s}, \mathrm{Me})$, $2.67(2 \mathrm{H}, \mathrm{q}, J 7.1 \mathrm{~Hz}), 4.48\left(2 \mathrm{H}, \mathrm{s}, \mathrm{CH}_{2}\right), 7.31(2 \mathrm{H}, \mathrm{d}, J 8.0 \mathrm{~Hz}), 7.55(2 \mathrm{H}, \mathrm{d}, J 8.0 \mathrm{~Hz}), 7.69(1 \mathrm{H}, \mathrm{s}) ; \mathrm{MS}$ (EI) m/e $222\left(\mathbf{M}^{+}, 30\right), 193\left(\mathrm{M}^{+}-29,100\right), 128\left(\mathrm{M}^{+}-94,40\right)$; [HRMS (EI) $m / z 222.0809\left(\mathrm{M}^{+}\right) . \mathrm{C}_{13} \mathrm{H}_{15} \mathrm{ClO}$ requires $M, 222.0811]$.

Preparation of 3-(chloromethyl)-4-phenyl-3-buten-2-one (3g).

This compound was prepared in the same manner as that described above: $75 \mathrm{mg}$ (77\%); a colorless oil; IR ( $\mathrm{KBr}) \vee 1640 \mathrm{~cm}^{-1}(\mathrm{C}=\mathrm{O}) ;{ }^{1} \mathrm{H}-\mathrm{NMR}\left(\mathrm{CDCl}_{3}, 300 \mathrm{MHz}\right) \delta 2.52(3 \mathrm{H}, \mathrm{s}, \mathrm{Me}), 4.46\left(2 \mathrm{H}, \mathrm{s}, \mathrm{CH}_{2}\right)$, 7.31-7.50 (3H, m, Ar), 7.51-7.61 (2H, m, Ar), $7.71(1 \mathrm{H}, \mathrm{s})$; MS (EI) m/e $194\left(\mathrm{M}^{+}, 100\right), 115\left(\mathrm{M}^{+}-79,40\right)$, $43\left(\mathrm{M}^{+}-151,40\right)$; [HRMS (EI) $m / z 194.0498\left(\mathrm{M}^{+}\right) . \mathrm{C}_{11} \mathrm{H}_{11} \mathrm{ClO}$ requires $\left.M, 194.0492\right]$.

Preparation of 3-(chloromethyl)-4-nonyl-3-buten-2-one (3h).

This compound was prepared in the same manner as that described above: $62 \mathrm{mg}(50 \%)$; a colorless oil; IR (KBr) v $1640 \mathrm{~cm}^{-1}(\mathrm{C}=\mathrm{O}) ;{ }^{1} \mathrm{H}-\mathrm{NMR}\left(\mathrm{CDCl}_{3}, 300 \mathrm{MHz}\right) \delta 0.83(3 \mathrm{H}, \mathrm{t}, J$ 7.1 Hz, Me), 1.10-1.40 $\left(12 \mathrm{H}, \mathrm{m}, \mathrm{CH}_{2}\right), 1.40-1.60\left(2 \mathrm{H}, \mathrm{m}, \mathrm{CH}_{2}\right), 2.36(3 \mathrm{H}, \mathrm{s}, \mathrm{Me}), 2.34(2 \mathrm{H}, \mathrm{td}, J$ 7.6, $7.6 \mathrm{~Hz}), 4.32\left(2 \mathrm{H}, \mathrm{s}, \mathrm{CH}_{2}\right)$, $6.85(1 \mathrm{H}, \mathrm{t}, J 7.6 \mathrm{~Hz})$; MS (EI) m/e $244\left(\mathrm{M}^{+}, 20\right), 209\left(\mathrm{M}^{+}-35,40\right), 109\left(\mathrm{M}^{+}-135,70\right), 43\left(\mathrm{M}^{+}-201,100\right)$; [HRMS (EI) $m / z 244.1596\left(\mathrm{M}^{+}\right) . \mathrm{C}_{14} \mathrm{H}_{25} \mathrm{ClO}$ requires $M, 244.1594$ ].

\section{X-Ray Crystallography}

Suitable single crystals of compounds 1a and 3a were mounted on the tip of a glass capillary. Data were collected on a Rigaku AFC7R diffractometer with graphite-monochromated Mo-K $(\alpha)$ radiation $\lambda=$ $0.71069(\AA)$ using the $\omega-2 \theta$ technique at $20^{\circ} \mathrm{C}$. The data were corrected for Lorentz polarization effects. The structure was solved by direct methods and expanded using Fourier techniques [16]. The nonhydrogen atoms were refined anisotropically by full-matrix least squares. All hydrogen atoms were 
included in the calculated positions. All calculations were performed using the TEXSAN crystallographic software package. The resulting crystal structures have been deposited at the Cambridge Crystallographic Data Center and have been allocated deposition numbers CCDC 144817 for 1a and CCDC 142973 for 3a, respectively.

\section{References and Notes}

1. For reviews, see: (a) Ciganek, E. Org. React. 1997, 51, 201; (b) Basavaiah, D.; Rao, P. D.; Hyma, R. S. Tetrahedron, 1996, 52, 8001; (c) Drewes, S. E.; Roos, G. H. P. Tetrahedron, 1988, 44, 4653.

2. Brzezinski, L. J.; Rafel, S.; Leahy, J. M. J. Am. Chem. Soc. 1997, 119, 4317.

3. Marko, I. E.; Giles, P. G.; Hindley, N. J. Tetrahedron, 1997, 53, 1015.

4. Richter, H.; Jung, G. Tetrahedron Lett. 1998, 39, 2729.

5. Barrett, A. G. M.; Cook, A. S.; Kamimura, A. J. Chem. Soc., Chem. Commun. 1999, 2533.

6. Kunidig, E. P.; Xu, L. H.; Romanens, P.; Bernardinelli, G. Tetrahedron Lett. 1993, 34, 7049.

7. Aggarwal, V.; Mereu, A.; Tarver, G. J.; MaCague, R. J. Org. Chem. 1998, 63, 7183.

8. Kawamura, M.; Kobayashi, S. Tetrahedron Lett. 1999, 40, 1539.

9. (a) Kataoka, T.; Iwama, T.; Tsujiyama, S.-i.; Iwamura, T.; Watanaba, S.-i. Tetrahedron, 1998, 54, 11813. (b) Kataoka, T.; Iwama, T.; Kinoshita, S.; Tsujiyama, Y.; Iwamura, T.; Watanabe, S. Synlett. 1999, 197. (c) Kataoka, T.; Iwama, T.; Tsujiyama, S.; Kanematsu, K.; Iwamura, T.; Watanabe, S. Chem. Lett. 1999, 257; (d) Kataoka, T.; Iwama, T.; Tsujiyama, S. J. Chem. Soc., Chem. Commun. 1998, 197. (e) Iwama, T.; Tsujiyama, S.-I.; Kinoshita, H.; Kanamatsu, K.; Tsurukami, Y.; Iwamura, T.; Watanabe, S.-I.; Kataoka, T. Chem. Pharm. Bull. 1999, 47, 956.

10. Ono, M.; Nishimura, K.; Nagaoka, Y.; Tomioka, K. Tetrahedron Lett. 1999, 40, 1509.

11. Nagaoka, Y.; Yomioka, K. J. Org. Chem. 1998, 63, 6428.

12. Li, G.; Gao, J.; Wei, H.-X.; Enright, M. Org. Lett. 2000, 2, 617.

13. Shi, M.; Jiang, J.-K.; Feng, Y.-S. Org. Lett., 2000, 2, 2397.

14. The X-ray crystal data for compound 1a: Empirical formula: $\mathrm{C}_{11} \mathrm{H}_{12} \mathrm{ClNO}_{4}$; Formula Weight: 257.67; Crystal Color, Habit: colorless, column; Crystal dimensions: 0.28 x 0.30 x 0.18 mm; Crystal system: orthorhombic; Lattice type: primitive; Lattice parameters: $\mathrm{a}=10.615(1) \AA, \mathrm{b}=14.277(1) \AA$, $\mathrm{c}=$ 7.838(1) $\AA$, V = 1187.8(3) $\AA^{3}$; Space group: $\mathrm{P} 22_{1} 2_{1}(\# 19) ; \mathrm{Z}_{\text {value }}=4 ; \mathrm{D}_{\text {clalc }}=1.441 \mathrm{~g} / \mathrm{cm}^{3} ; \mathrm{F}_{000}=$ $536.00 ; \mu(\mathrm{MoK} \alpha)=3.23 \mathrm{~cm}^{-1}$; Residuals: R; Rw =0.065; 0.052 .

15. (a) Antler, M.; Laubengayer, A. W. J. Am. Chem. Soc., 1955, 77, 5250. (b) Bharathi, P.; Periasamy, M. Org. Lett., 1999, 1, 857. (c) Blake, A. J.; Collier, P. E.; Dunn, S. C.; Li, W.-S.; Mountford, P.; Shishkin, O. V. J. Chem. Soc., Dalton Trans., 1997, 9, 1549. (d) Vol'pin, M. E.; Shur, V. B.; Berkovich, E. G. Inorg. Chim. Acta, 1998, 280, 264. (e) Sinnema, P.-J.; van der Veen, L.; Spek, A. L.; Veldman, N.; Teuben, J. H. Organometallics, 1997, 16, 4245.

16. Shi, M.; Jiang, J.-K. Tetrahedron, 2000, 56, 4793. The X-ray crystal data of compound 3a: Empirical Formula: $\mathrm{C}_{22} \mathrm{H}_{20} \mathrm{~N}_{2} \mathrm{O}_{6} \mathrm{Cl}_{2}$; Formula Weight: 479.32; Crystal Color, Habit: colorless, prismatic; Crystal Dimensions: 0.20 × 0.20 x $0.30 \mathrm{~mm}$; Crystal System: monoclinic; Lattice Type: primitive; Lattice Type: $a=7.524(2) \AA, b=17.541(3) \AA, c=17.07(1) \AA, \beta=98.64(4)^{\mathrm{o}}, \mathrm{V}=2227(1) \AA^{3}$; Space group: 
$\mathrm{P} 21 / \mathrm{n}(\# 14) ; \mathrm{Z}$ value $=4 ; \mathrm{D}_{\text {calc }}=1.429 \mathrm{~g} / \mathrm{cm}^{3} ; \mathrm{F}_{000}=992.00 ; \mathrm{u}(\mathrm{MoK} \alpha)=3.33 \mathrm{~cm}^{-1} ; \mathrm{R}=0.066, \mathrm{R}_{\mathrm{w}}=$ 0.061. TEXSAN, Crystal Structure Analysis Package, Molecular Structure Corporation, Houston, TX, 1985 and 1992.

Sample Availability: Samples are available from the authors.

(C) 2001 by MDPI (http://www.mdpi.org). Reproduction is permitted for noncommercial purposes. 